2. To: (Receiving Organization)

CHG Characterization Field Engineering

5. Proj./Prog./Dept./Div.:

Characterization Project

8. Originator Remarks: ESR-98-03

1) A NEPA review was conducted as shown by the signature from Environmental which signifies there concurrence.

2) Design Verification performed by Informal review per HNF-IP-0842 Vol IV, Section 4.24

3) The Design Criteria is addressed in WHC-SD-ETP-193, "In-Situ Vapor Sampling System Continuing Development."

4) The Safety Classification for the Carts is General Services (GS).

11. Receiver Remarks: llA. Design Baseline Document? [X] Yes [] No

\begin{tabular}{l|c} 
3. From: (Originating Organization) & 4. Related EDT No.: \\
Characterization Engineering & N/A \\
\hline 6. Design Authority/Design Agent/Cog. Engr.: & 7. Purchase Order No.: \\
GP Janicek/DD Wanner & N/A
\end{tabular}

9. Equip./Component No.:

10. System/B/dg./Facility:

$200 \mathrm{G}$

12. Major Assm. Dwg. No.:

N/A

13. Permit/Permit Application No.:

N/A

14. Required Response Date:

N/A

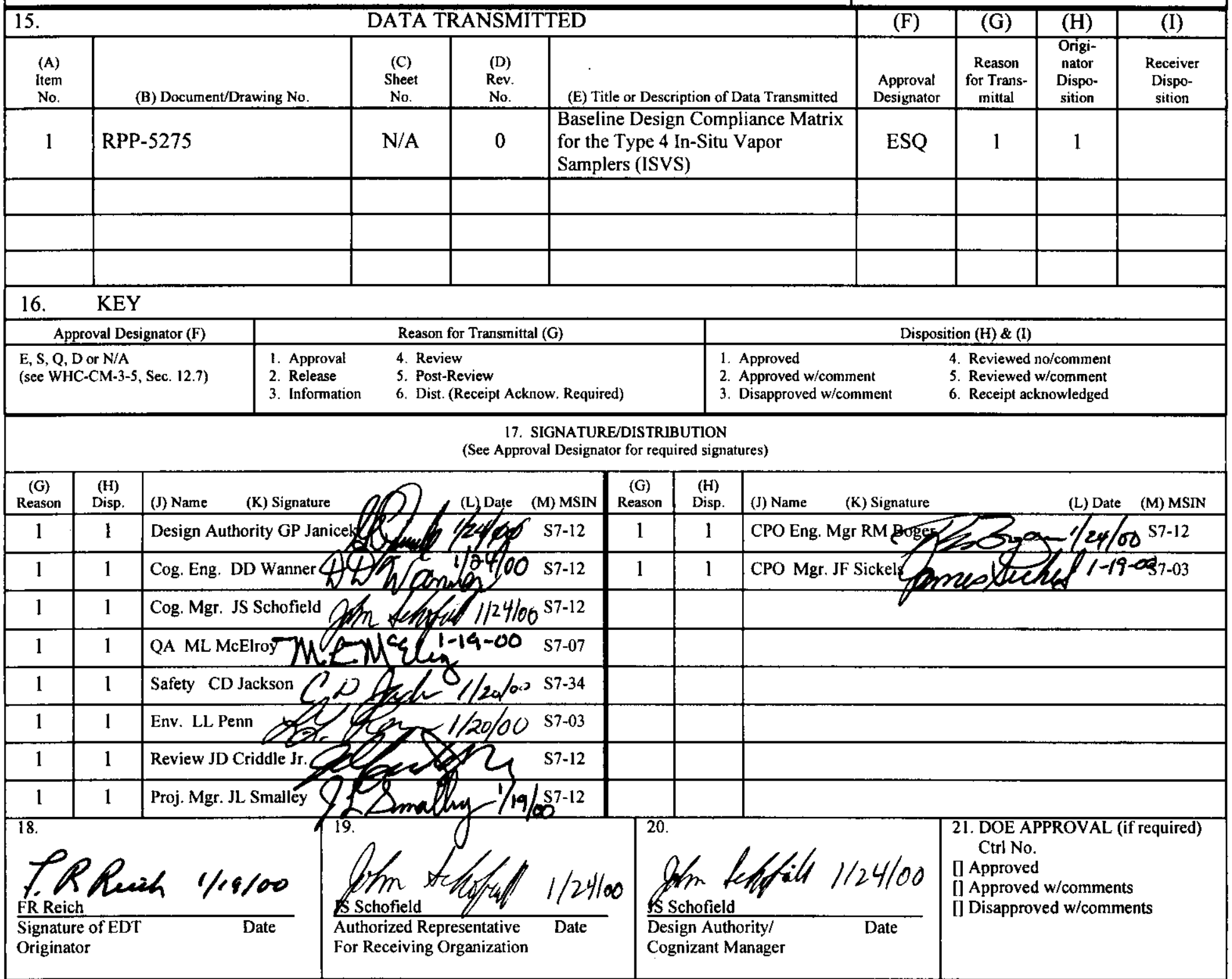




\title{
Baseline Design Compliance Matrix for the Type 4 In-Situ Vapor Samplers (ISVS)
}

\author{
R. M. BOGER \\ CH2M HILL Hanford Group, Inc., Richland, WA 99352 \\ U.S. Department of Energy Contract DE-AC06-96RL13200
}

EDT/ECN: 627889

UC: 2000

Org Code: 74900

B\&R Code: EW3130000

Charge Code: $102254 / \mathrm{E} 100$

Total Pages: 17

Key Words: Type 4 In-Situ Vapor Sampler (ISVS), vapor sampler, Design Compliance Matrix, DCM

Abstract:

The DOE has identified a need to sample vapor space and exhaust ducts in waste tanks that store radioactive waste. This document provides the Design Compliance Matrix (DCM) for the Type 4 In-Situ Vapor Sampling (ISVS) system that is used for completing this sampling function. The DCM identifies the design requirements and the source of the requirements for the Type 4 ISVS system. DCMs are a single-source compilation design requirements for sampling and sampling support equipment and support the configuration management of these systems.

TRADEMARK DISCLAIMER. Reference herein to any specific commercial product, process, or service by trade name, trademark, manufacturer, or otherwise, does not necessarily constitute or imply its endorsement, recommendation, or favoring by the United States Government or any agency thereof or its contractors or subcontractors.

Printed in the United States of America. To obtain copies of this document, contact: Document Control Services, P.O. Box 950, Mailstop H6-08, Richland WA 99352, Phone (509) 372-2420; Fax (509) 376-4989.
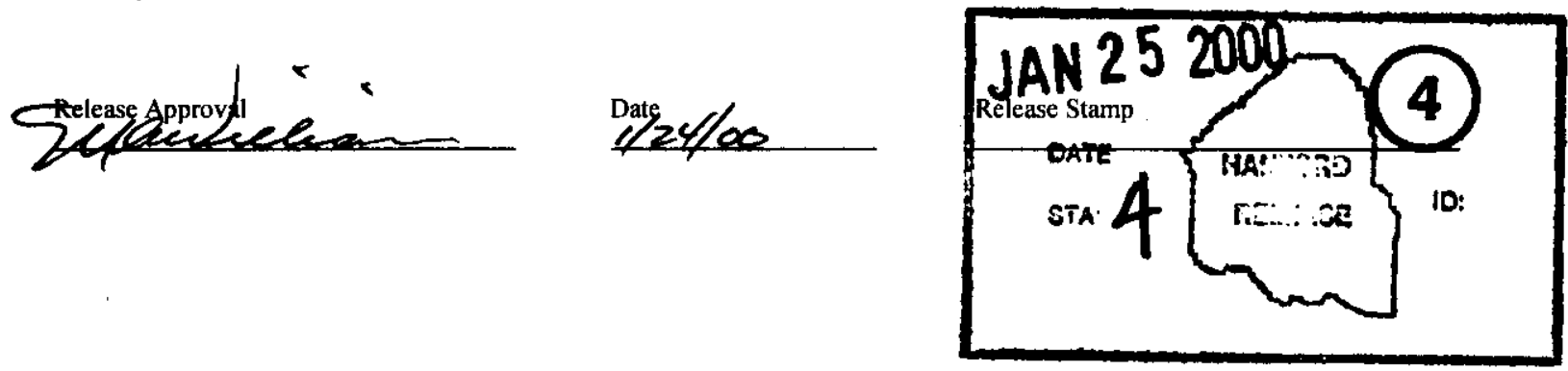


\section{Hanford NEPA Screening Form}

For NEPA roquirements, $\infty$ HNE-PRO-192.

Anewer quations YES or NO, and lint NUMBER if applicable.

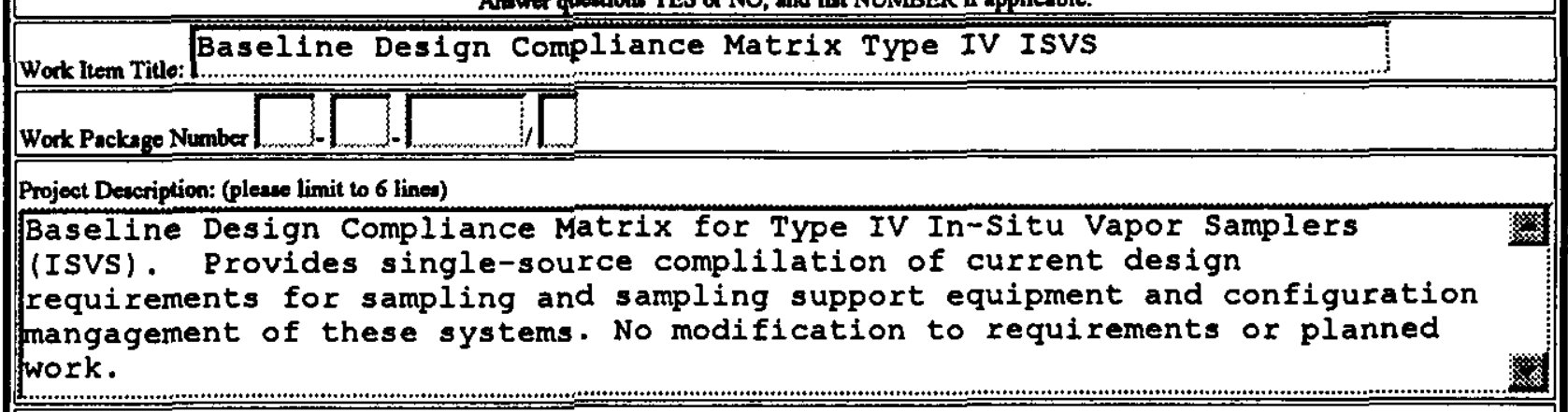

\begin{tabular}{|c|c|}
\hline & INTEGRAL ELEMENTS \\
\hline$\therefore$ Yen No & Will work threaten to violate environmental lawn, regulations, permits, of uffety requirementa? \\
\hline C: Yea No & $\begin{array}{l}\text { Will work involve construction/expanvion of waste treatment, atorage, diepoual facilitiea? } \\
\text { Will hezardous subatancea be disturbed allowing uncontrolled/unpermittod releases? }\end{array}$ \\
\hline
\end{tabular}

goto B.

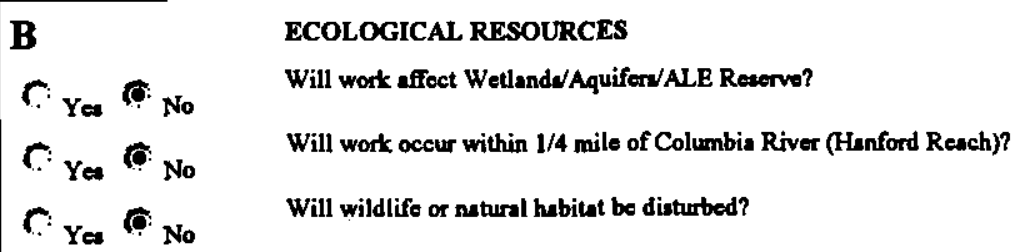

If all answen aro NO, go to C; If any anower is YES, get Ecological Review. NUMBER:

C CULTURAL RESOURCES

C: Yes No Does the work require excavations or urface disturbing activities? Obtain permit if required.

C. Yea No

Does the work require building or equipment modification to linted historic structures?

If all anwwers aro NO, and all conditions have been met and the SWCX applies, so to D; If any anower is YES, a Cultural Resources Review is required. Liat review NUMBER:

NOTE: If advene impacts are identified, goto $\mathrm{E}$.

\begin{tabular}{|c|c|}
\hline D & SITE-WDE CATEGORICAL EXCLUSION (SWCX) \\
\hline$C_{\text {Yes }} \overbrace{\text { No }}$ & In evaluating potential environmental impacta, was Waste Minimization considered? See HNF-PRO-462. \\
\hline 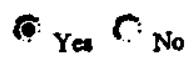 & In the work covered by \& SWCX? \\
\hline
\end{tabular}

If YES, liat SWCX that applies: A1.............................................. print form and sign; If NO, Go to

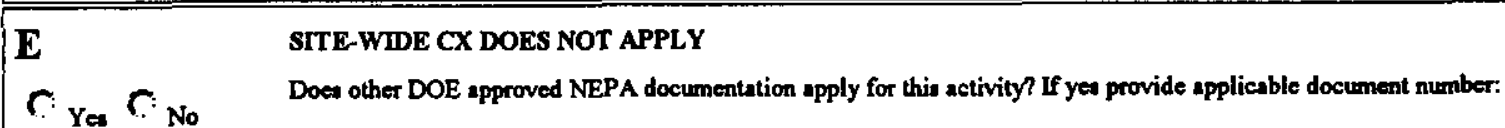

DOE/EA- D.............. DOE/EIS-

If CX or EA preparation may be needed, contact WMH NEPA Team 372-2484 or 376-1373.

SWCX b vot valid until any applicable

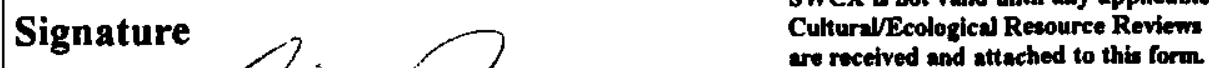

Signature
Reviewget

A-6001-497(3/98) 


\title{
BASELINE DESIGN COMPLIANCE MATRIX FOR THE TYPE 4 IN-SITU VAPOR SAMPLERS
}

\author{
Prepared For \\ River Protection Project \\ CH2M HILL Hanford Group, Inc. \\ Characterization Engineering \\ Richland, Washington
}

By F. R. Reich

COGEMA Engineering Corporation

Richland, Washington

January 2000 


\section{BASELINE DESIGN COMPLIANCE MATRIX \\ FOR THE TYPE 4 IN-SITU \\ VAPOR SAMPLERS}

Table of Contents

1.0 BACKGROUND

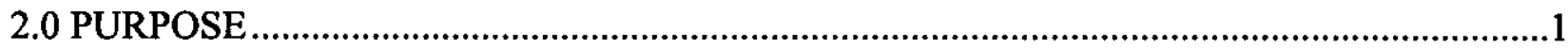

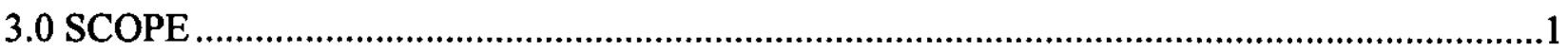

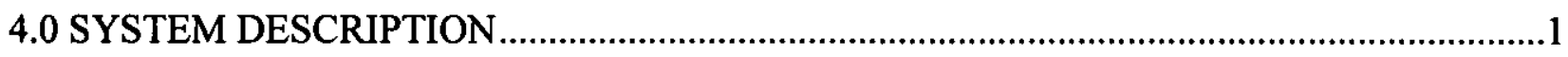

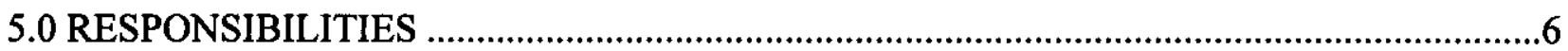

6.0 REQUIREMENTS

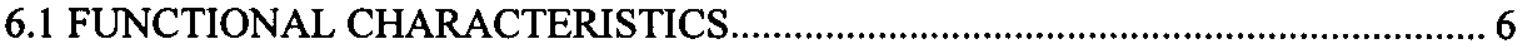

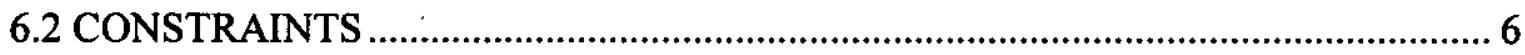

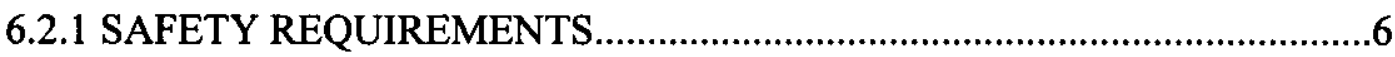

6.2.2 ENVIRONMENTAL REGULATIONS .....................................................

6.2.3 MAJOR DESIGN CODES ..........................................................................

6.2.4 INSTRUMENT CALIBRATION REQUIREMENTS .................................7

6.3 SOLUTION TO REQUIREMENTS .................................................................. 7

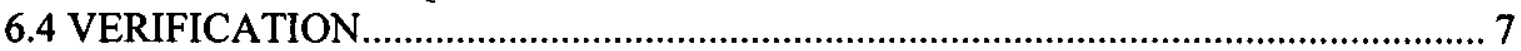

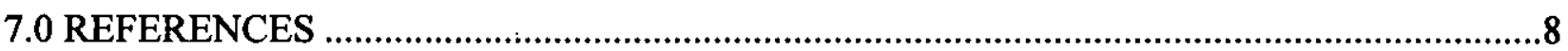

Figures

Figure 1. Type 4 In Situ Vapor Sampling System Cart ........................................................ 3

Figure 2. Type 4 In Situ Vapor Sampling System Cart ................................................................. 4

Figure 3. Typical Sampling Head Arrangement of Sorption Tubes and Particulate Filters.......... 5

Tables

Table 1. Design Compliance Matrix for Type 4 In Situ Vapor Sampling System ........................ 9

Table 2. Instrumentation Calibration Criteria. 
RPP-5275 Rev. 0

\section{BASELINE DESIGN COMPLIANCE MATRIX \\ FOR THE TYPE 4 IN-SITU \\ VAPOR SAMPLERS}

\subsection{BACKGROUND}

Underground storage tanks on the Hanford Site, that store radioactive wastes, have been identified as facilities that can emit hazardous vapors. The Type 4 (sometimes referred to as Type IV) In-Situ Vapor Sampler (ISVS) system is a portable system that is designed for in-situ sampling of the vapor space in the radioactive waste storage tanks. The ISVS uses a "sorption" tube method of collecting vapors in situ. After samples are obtained with the sorption tubes, they are transported to a laboratory for vapor extraction and analysis. The ISVS cart contains mass flow sensors, temperature sensors, and flow totalizers that provide accurate volume and temperature measurements that are needed in establishing vapor concentrations.

\subsection{PURPOSE}

Characterization Engineering is chartered with supporting Characterization Project Operations through provision, maintenance, and modification of tank waste sampling and other equipment. The functional and design criteria for this equipment are varied in category, service, and application. Design Compliance Matrix (DCM) documents provide a single-source compilation of traceable, current design requirements for sampling and sampling support equipment and support the configuration management of these systems. A desk instruction for implementing the use of a DCM was issued (Boger 1999) to support all engineering design and design related activities performed on behalf of the Characterization Project.

\subsection{SCOPE}

This DCM document provides the base-line design requirements and the source of the requirements for the Type 4 ISVS sampling system that is used for vapor sampling in Hanford's radioactive waste tanks. Other system requirements are found in the System Design Document (Blanchard 1996a) and Engineering Task Plan (Blanchard 1996b). These documents should be consulted when making design changes to the Type 4 ISVS system. This DCM covers only the Type 4 ISVS system.

\subsection{SYSTEM DESCRIPTION}

The Type 4 ISVS system includes three major assemblies: sampling cart, tube bundle, and sampling head. The ISVS cart, shown in Figure 1, consists of an instrumentation cabinet, vacuum air pump components, a manifold, and various valves, flow meters, flow totalizers, rotameters, and filters mounted on a hand truck. A schematic of the cart's flow diagram (from drawing H-2-825313) is shown in Figure 2. A tube bundle (14 small-diameter tubes approximately $50 \mathrm{ft}$ in length) connects the cart with the sampling head and provides a separate 
sampling tube for the SUMMA ${ }^{\mathrm{TM}}$ canister sampler. The sampling head shown in Figure 3 (Figure 3 is considered a typical arrangement of sorption tubes and filters) contains particulate filters, tritium-trap filters, multiple sorption tubes, and a thermocouple. The selection and arrangement of the sorption tubes and filters is dependent upon the vapor sampling needs identified in the Data Quality Objective and Sampling Analysis Plan documents that define tank sampling requirements.

The tube-bundle is used to lower the sampling head through a riser into a tank's vapor space. As shown in Figure 2, the ISVS cart has 5 flow channels that can be operated simultaneously. One of these channels is reserved for the SUMMA ${ }^{\mathrm{TM}}$ canister sampler. The other four channels are used with the sorption tubes and tritium-trap particulate filters in the sampling head. The cart is designed so that each flow channel can have a different flow rate. Each of the 4 channels has a mass flow meter and a flow totalizer that measures the total flow through its sorption tube. The flow rate and total accumulated flow requirements are dependent upon the type of sorption tubes and/or filters in the sampling head. Flow total is needed to obtain a concentration reading for the filters and sorption tubes in the sampling head. The SUMMA ${ }^{\mathrm{TM}}$ canister flow channel is purged using a stopwatch and a calibrated rotameter. The purging is completed at a specific flow rate and over a defined time to ensure that the tube is filled completely with tank gases prior to taking a SUMMA ${ }^{\mathrm{TM}}$ canister sample. The gases that are pulled through the sorption tubes, filters, and SUMMA ${ }^{\mathrm{TM}}$ canister tubing are "scrubbed" by filters on the cart before they are released to the atmosphere. Thermocouples on the sampling head and in the cart's gas manifold are used to measure vapor temperature.

After sampling is completed, the tube bundle with the sampling head is removed from the tank. The sample head is disconnected from the tube bundle and the ends of the sorption and filter channels are capped. The sampling head is bagged out with protective plastic and then readied for shipment to the laboratory. The tube used with the SUMMA ${ }^{\mathrm{TM}}$ canister is separated from the tube bundle and disposed of as waste. The SUMMA ${ }^{\mathrm{TM}}$ tube in the tube bundle is replaced for each sampling campaign to prevent cross-contamination from the previous sampling. Since the sorption tubes are in front of their sampling tubes, there can be no cross-contamination, and the tube bundle can be reused. 
Figure 1. Type 4 In Situ Lapor Sampling System cart

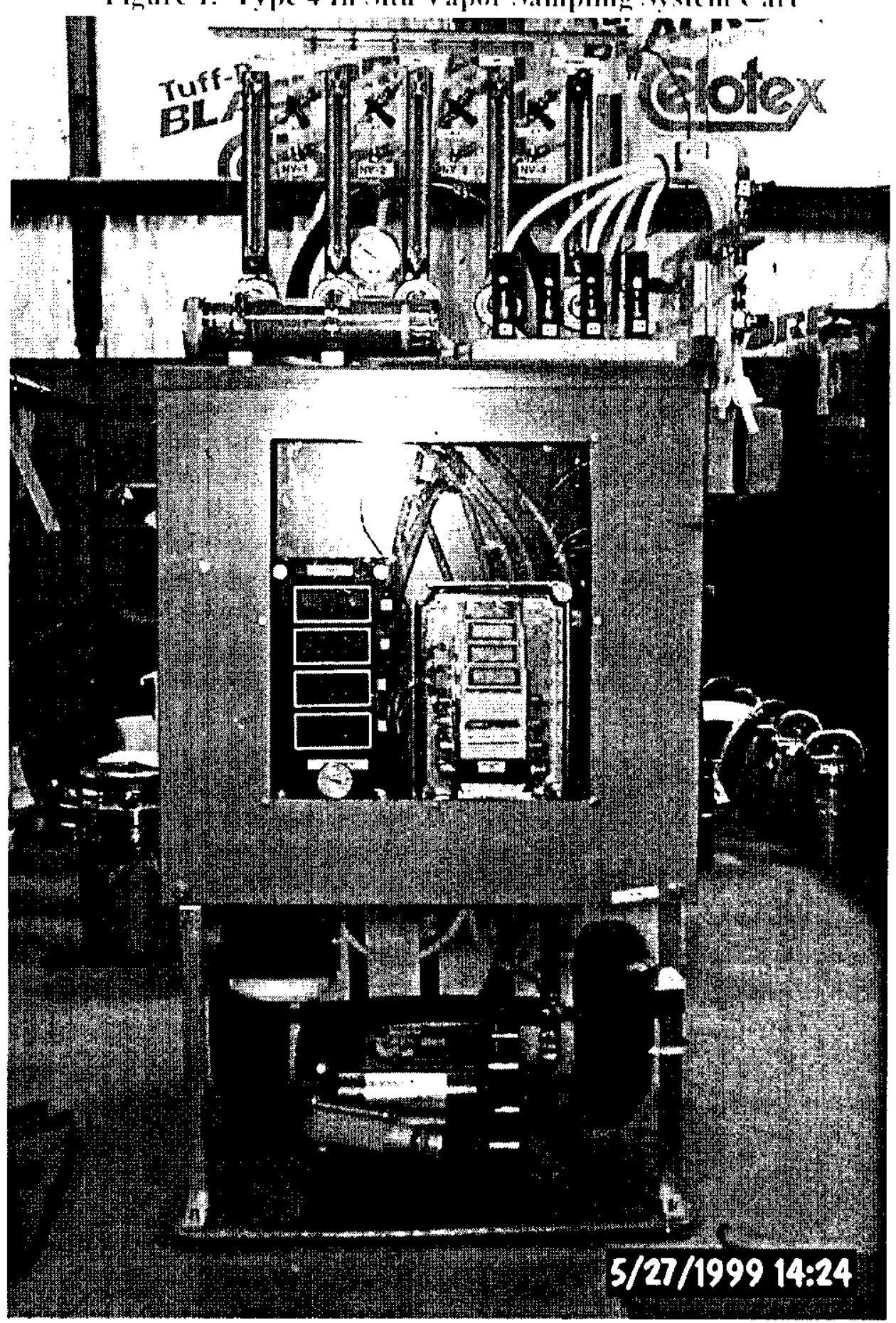




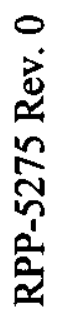
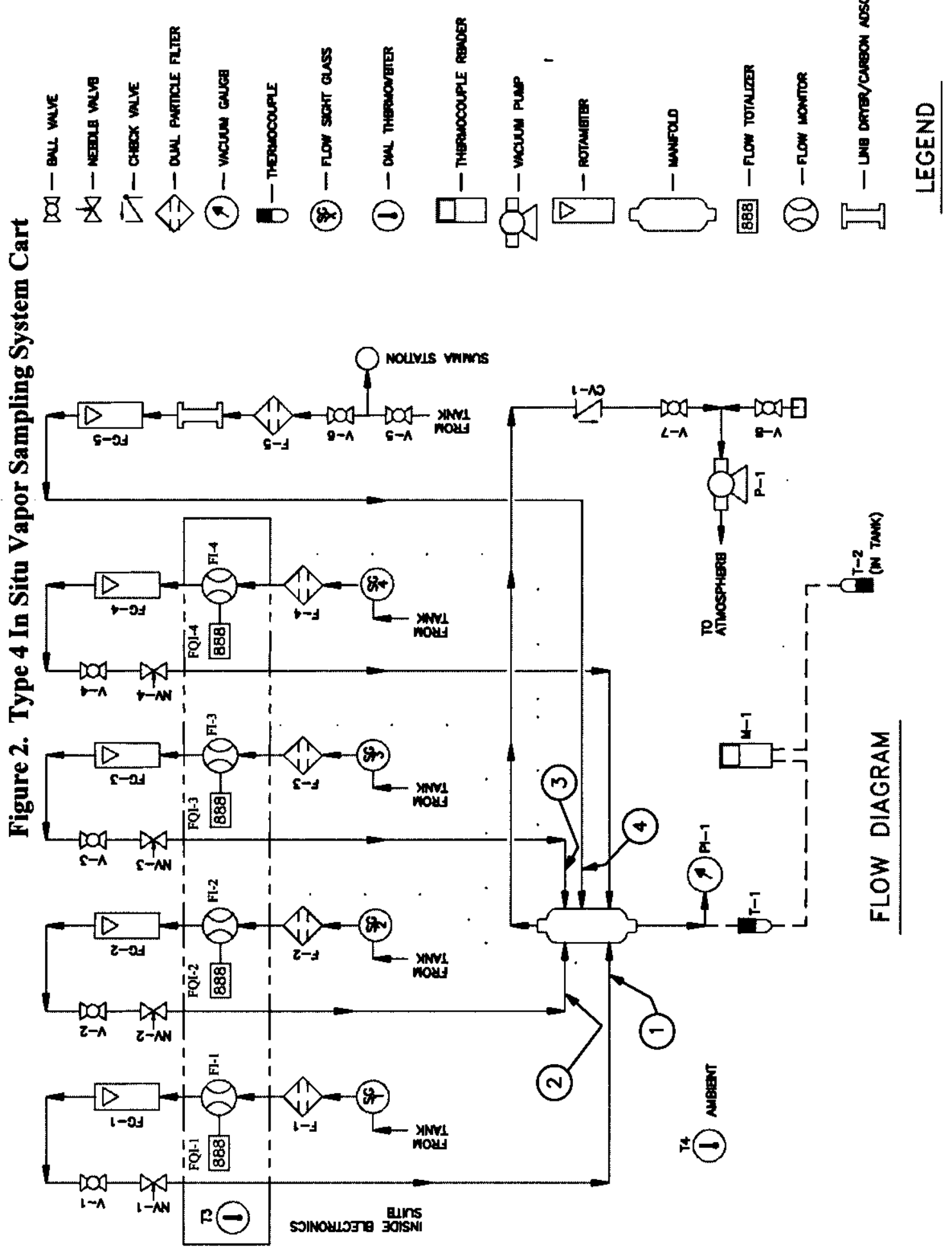
Figure 3. Typical Sampling Head Arrangement of Sorption Tubes and Particulate Filters.

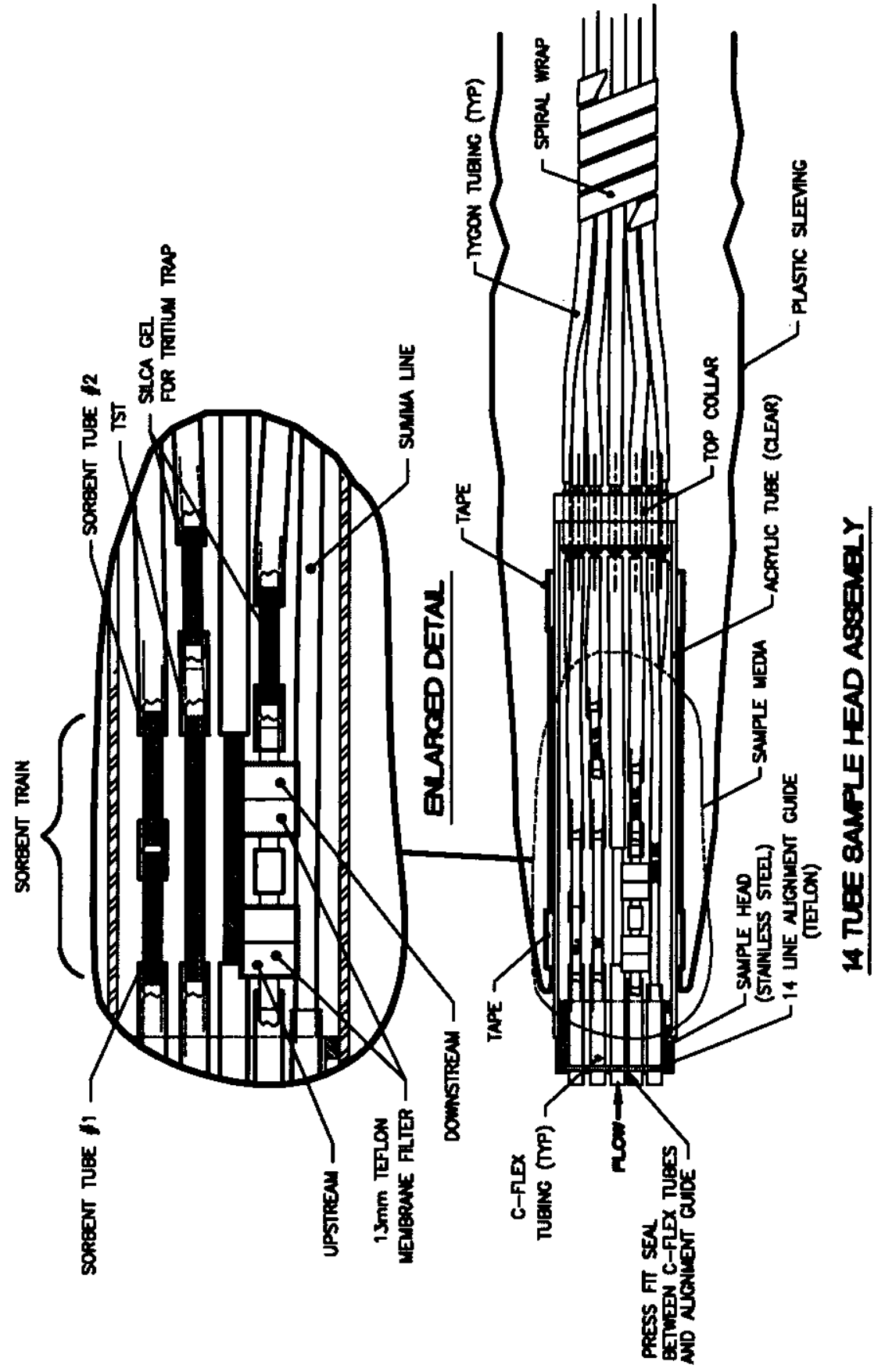




\subsection{RESPONSIBILITIES}

This DCM, and any portion thereof, is considered to be a baseline requirements document. Any changes to the DCM will require Safety, Quality Assurance, and Environmental approval in addition to that of the assigned Design Authority. The assigned Design Authority is responsible for proper preparation and maintenance of the DCM and exercises ownership of it on behalf of Characterization Equipment Engineering and Characterization Project Operations management.

\subsection{REQUIREMENTS}

The Design Compliance Matrix for the Type 4 ISVS system is shown in Table 1. The functions and requirements identified in Table 1, Column 2, are defined in WHC-SDWM-SDD-068 (Blanchard 1996a), and WHC-SD-WM-ETP-138 (DeFord 1996), and WHC-SD-WM-ETP-193 (Blanchard 1996b). These include functional requirements and constraints that are shown as safety, environmental, performance, interface, and design code requirements in Table 1.

\subsection{FUNCTIONAL CHARA CTERISTICS}

The ISVS samplers are part of the tank waste sampling equipment. The equipment is moved from tank to tank to perform sampling operations and will be used year round. The gas volume withdrawn from a tank is sufficiently low that there is no impact on the tank dome space pressure or ventilation.

The ISVS sampler interfaces with a tank riser and may be powered with a portable electrical generator or plugged into a local power source.

The ISVS sampler components are exposed to the Hanford climate (FDNW 1997a), natural phenomena (FDNW 1997b), and the tank vapor chemistry (PNNL 1999). The ISVS sampler components must operate under these conditions, have the strength to withstand deployment loads, and be constructed of material that is compatible with the environment.

\subsection{CONSTRAINTS}

Constraints ensure that the ISVS equipment meets accepted safety envelopes, is in compliance with environmental regulations and pertinent design codes, and meets the operability standards considered important by the Design Authority.

\subsubsection{SAFETY REQUIREMENTS}

The safety class of the Type 4 ISVS cart is General Service. There are no safety class or safety significant items associated with this system. Operation and maintenance of the ISVS system is performed to approved procedures or work documents utilizing standard River Protection Project (RPP) safety practices. 


\subsubsection{ENVIRONMENTAL REGULATIONS}

The pertinent environmental regulations limit radioactive and toxic air emissions. The governing radioactive air emission standard is Title 246-247 of the Washington Administrative Code (WAC). The governing toxic air pollutant standard is WAC 173460. Specific requirements for control of radioactive emissions are presented in WAC 246-247 and for control of toxic air pollutants are presented in WAC 173-460. ALARA is the system operational exposure goal. The ISVS system has been approved by DOE for collecting vapor samples from tank wastes (LMHC 1999b).

\subsubsection{MAJOR DESIGN CODE S}

The design codes of particular interest to ISVS sampler design is the National Electrical Code (NFPA 1998).

\subsubsection{INSTRUMENT CALIBRATION REQUIREMENTS}

The data quality requirements for the sample analysis and data obtained utilizing the Type 4 ISVS system are specified in HNF-SD-WM-DQO-021 (LMHC 1999a). Additional requirements may be specified in the individual tank sampling and analysis plan (TSAP). Table 8-3, Chemical and Radiological Analytical Requirements (LMHC 1999) specifies the criteria for the various analyses to be performed. All analyses listed are required to have a precision of $\pm 25 \%$ with an accuracy of $70 \%-130 \%$. There are no instrumentation-specific requirements for the ISVS carts stated at this time. Therefore, the instrumentation is calibrated to values based on engineering of the manufacturer's accuracy and operational requirements (Table 2, Instrumentation Calibration Criteria).

\subsection{SOLUTION TO REQUIREMENTS}

For each requirement the DCM lists a system attribute that satisfies the requirement. Columns 7 and 8 in Table 1 describe the manner in which the Type 4 ISVS system fulfills the functional requirements and constraints that are found in Column 2.

\subsection{VERIFICATION}

Columns 9 and 10 in Table 1 provide confirmation information that is needed to confirm that the design solution adequately meets the system requirements. 


\subsection{REFERENCES}

Blanchard, R. J., 1996a System Design Description for the In-Situ Vapor Sampling System, WHC-SD-WM-SDD-068. Rev. 0, July 1996, Westinghouse Hanford Company, Richland, Washington.

Blanchard, R. J., 1996b, In-Situ Vapor Sampling System Continuing Development, WHC-SD-WM-ETP-193, Rev. 0, May 1996, Westinghouse Hanford Company, Richland, Washington.

Boger, R. M. , Desk Instruction - Design Compliance Matrix, DI-CE-008-001, July 1999.

DeFord, D. K., 1996, In-Situ Vapor Sampling Cart Development Engineering Task Plan, WHC-SD-WM-ETP-128, Rev. 1A, January 1996, Westinghouse Hanford Company, Richland, Washington.

FDNW, 1997a, Design Climate Data for Hanford Site, SDC-5.1 GH-CLIM-01, June 1997.

FDNW, 1997b, Design Load for Facilities, SDC-4.1 GC-LOAD-01, June 1997.

LMHC, 1999a, Data Quality Objectives for Regulatory Requirements for Hazardous and Radioactive Air Emissions Sampling and Analysis, HNF-SD-WM-DQO-021, Rev., 1, 1999, Lockheed Martin Hanford Corporation, Richland, Washington.

LMHC, 1999b, Control of Airborne Radioactive Emissions for Frequently Performed TWRS Work Activities (ALARACT Demonstrations), HNF-4327, Rev. 0,1999, Lockheed Martin Hanford Corporation, Richland, Washington.

NFPA 1998, NFPA 70 National Electrical Code 1999Edition, 1998, National Fire Protection Association, Inc., Quincy, Massachusetts.

PNNL 1999, Tank Characterization Database, Version 3.24, 1999, Pacific Northwest National Laboratory, Richland, Washington.

Tank Waste Information Network Systems (TWINS), (Tank waste data base found at web site: http://twins.pnl.gov:8001/data/data.asp)

WAC 246-247, 1995, Radiation Protection--Air Emissions, Washington Administrative Code, as amended.

H-2-825313 Vapor Sampling Cart Assembly (Latest Revision). 


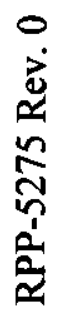

\begin{tabular}{|c|c|c|c|c|}
\hline & 焉 & 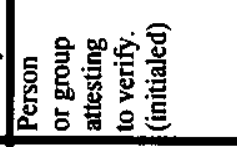 & & \\
\hline 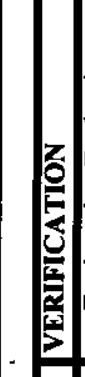 & 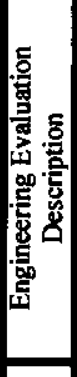 & 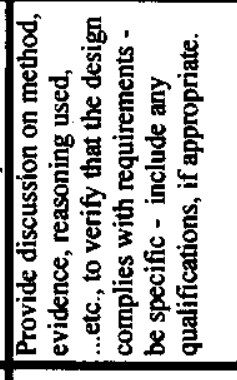 & 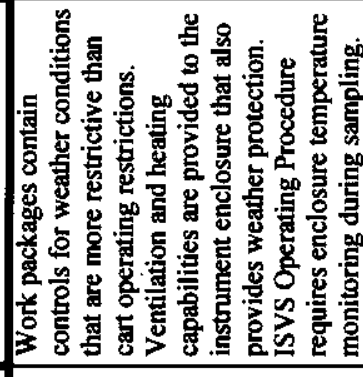 & 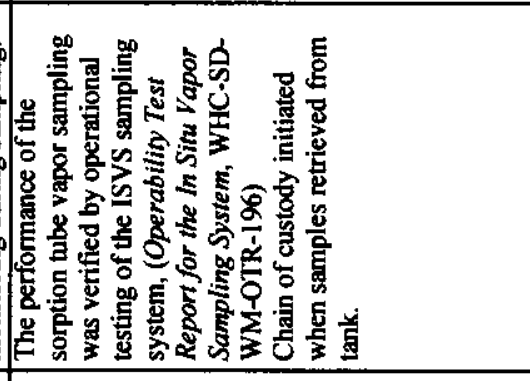 \\
\hline & . & 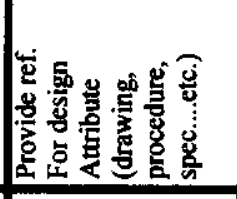 & & 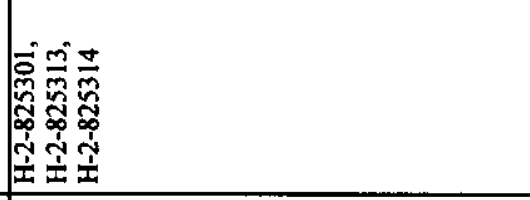 \\
\hline 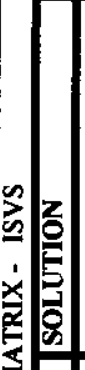 & 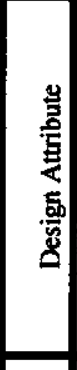 & 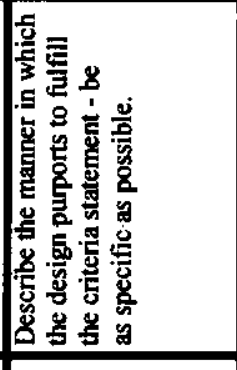 & 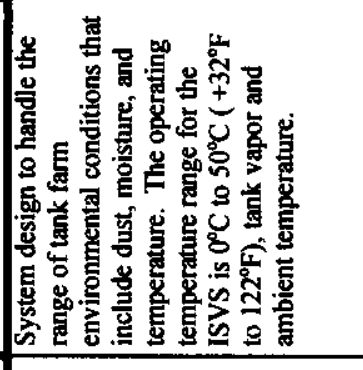 & 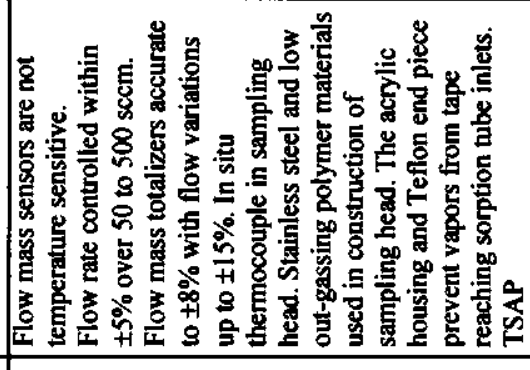 \\
\hline & 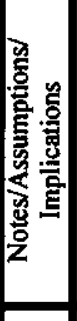 & 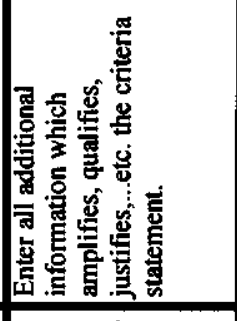 & 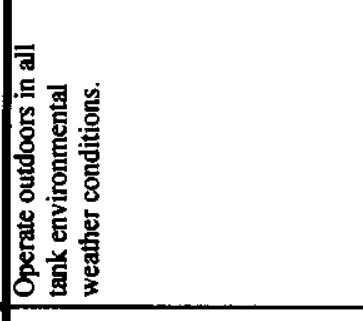 & 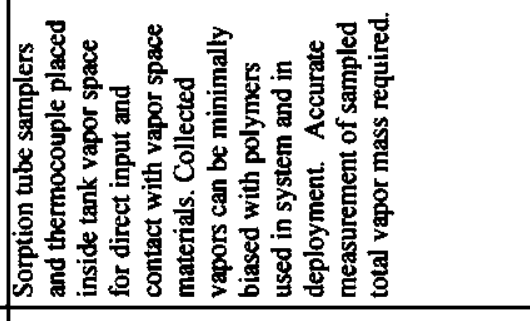 \\
\hline & 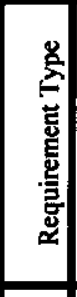 & 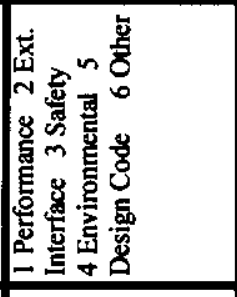 & : & 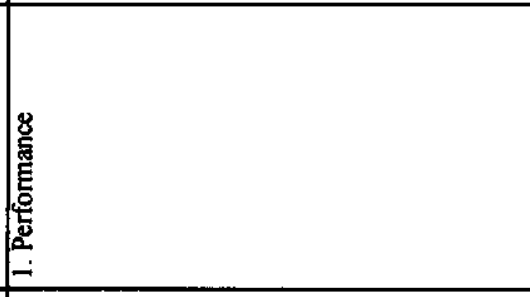 \\
\hline & 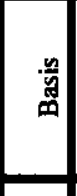 & 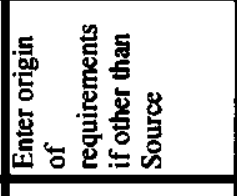 & & 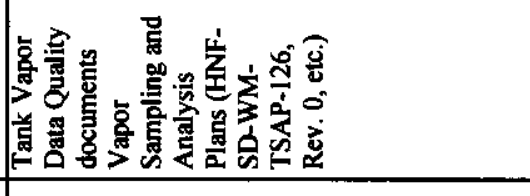 \\
\hline & 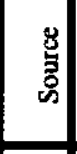 & 总寒安 & 家宗 & 家宣 \\
\hline & . & 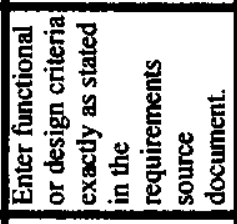 & 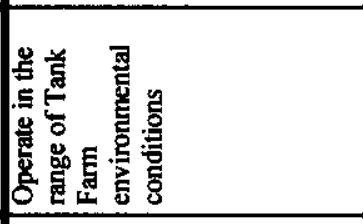 & 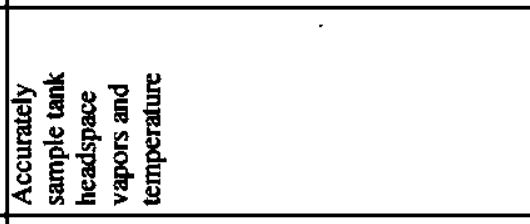 \\
\hline & $\underline{E}$ & 帠焉字 & & IN \\
\hline
\end{tabular}




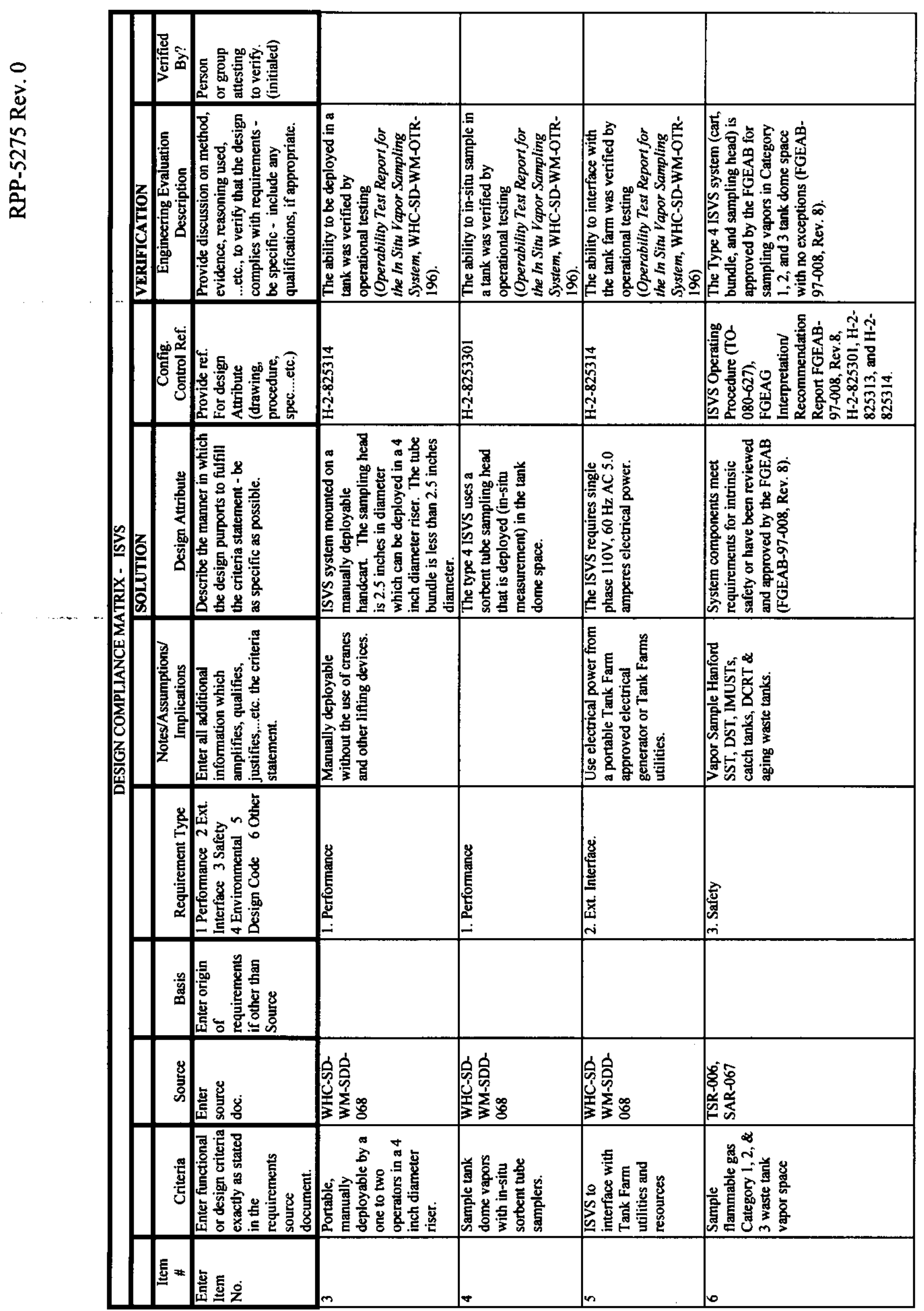




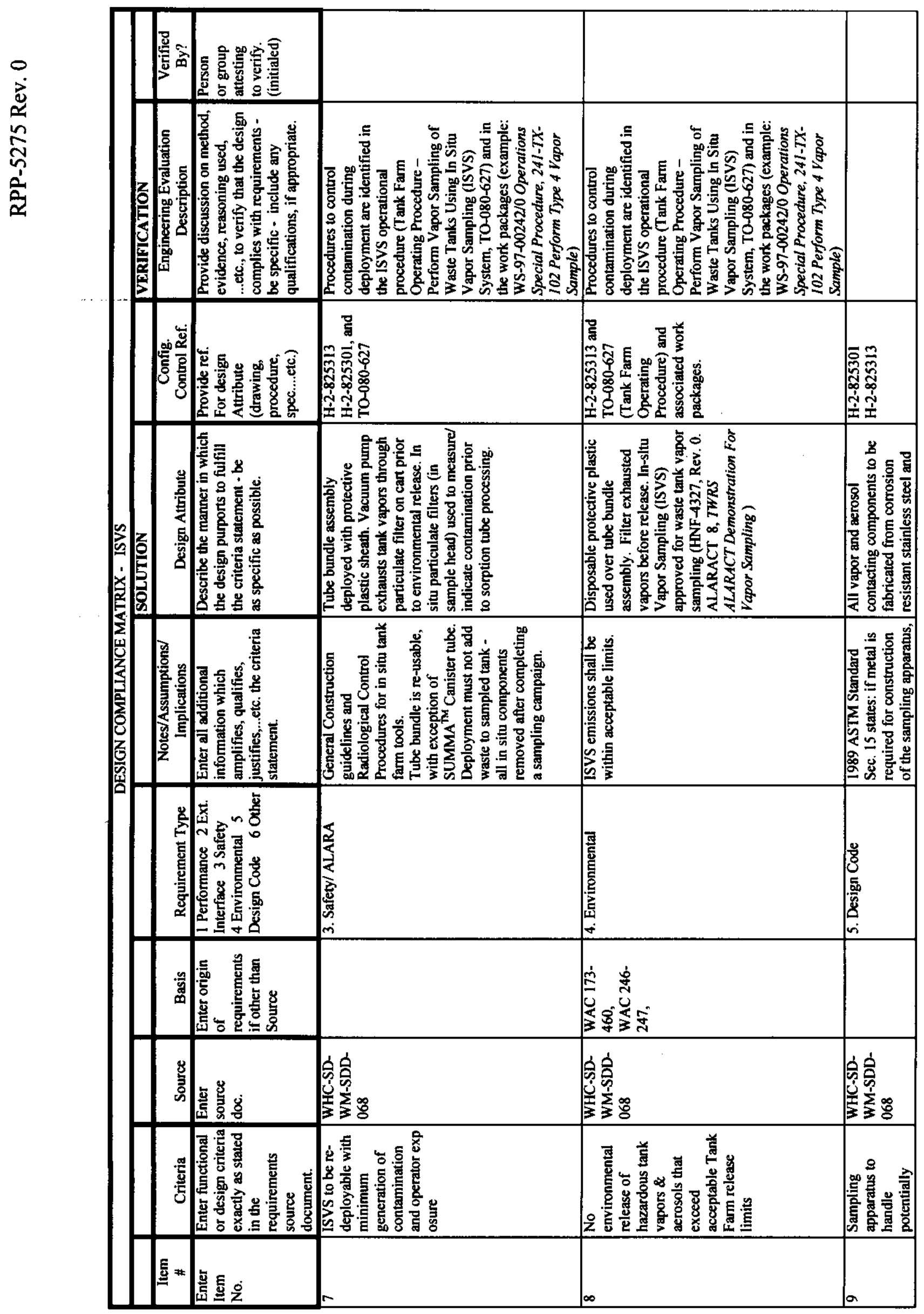




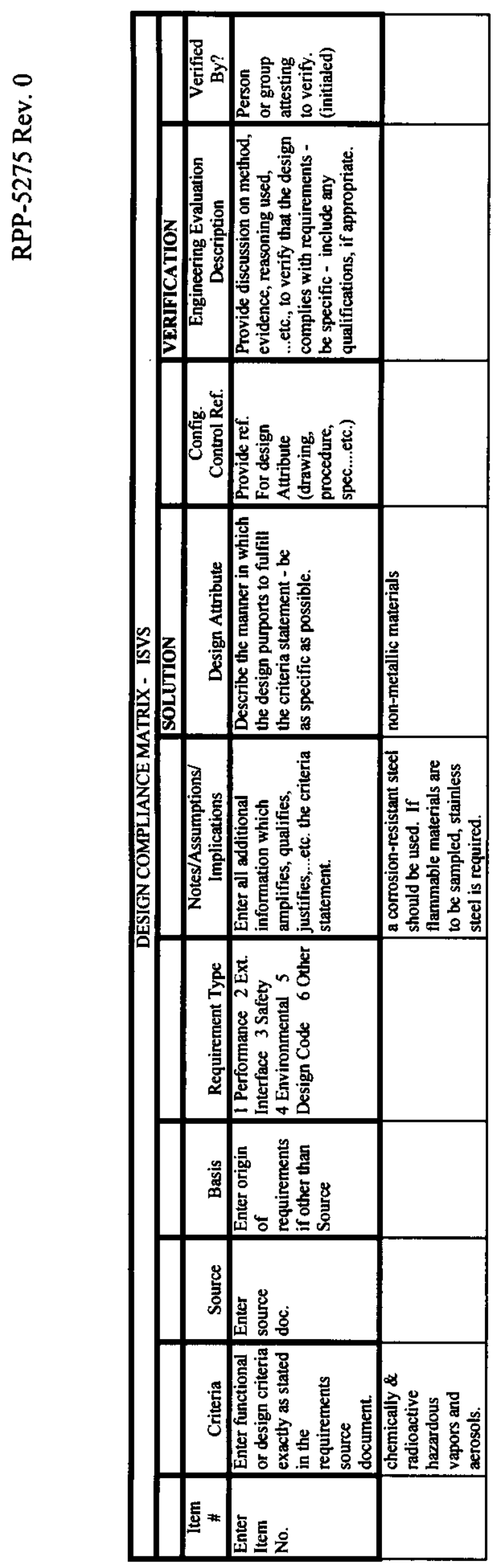


Table 2. Instrumentation Calibration Criteria

\begin{tabular}{|c|c|c|c|}
\hline $\begin{array}{l}\text { Equipment } \\
\text { Identification }\end{array}$ & Part Number & $\begin{array}{l}\text { Manufacturer } \\
\text { Calibration } \\
\text { Specification }\end{array}$ & $\begin{array}{l}\text { Calibration } \\
\text { Accuracy }\end{array}$ \\
\hline $\begin{array}{l}\text { FG-1, FG-2, } \\
\text { FG-3. FG-4 }\end{array}$ & $\begin{array}{l}\text { Rotameter, } \\
\text { AALBORG \#112-02 }\end{array}$ & $\pm 2 \%$ full scale (fs) & $\begin{array}{l}\text { N/A (flow } \\
\text { indication only) }\end{array}$ \\
\hline FG-5 & $\begin{array}{l}\text { Rotameter, } \\
\text { AALBORG \#102-05 }\end{array}$ & $\pm 2 \%$ fs & $\pm 2 \% \mathrm{fs}$ \\
\hline$\overline{\mathrm{PI}}-1$ & $\begin{array}{l}\text { Vacuum Gage, } \\
\text { ASHCROFT } \\
\# 2105-318\end{array}$ & $\pm 3 \%$ fs & $\pm 3 \%$ fs \\
\hline $\begin{array}{l}\text { FI-1, FI-2, } \\
\text { FI-3, FI-4 }\end{array}$ & $\begin{array}{l}\text { Mass Flow Meter, } \\
\text { SIERRA } \\
\text { \#822-13-OV1-PV-V1 }\end{array}$ & $\begin{array}{l} \pm 1.5 \% \text { fs } \\
\left(15-25^{\circ} \mathrm{C}, 5-60 \text { psia }\right) \\
0.15 \% \mathrm{fs} /{ }^{\circ} \mathrm{C} \\
0.01 \% \mathrm{fs} / \mathrm{psia}\end{array}$ & $\begin{array}{l} \pm 2 \% \text { fs (total error } \\
\text { with totalizer } \\
\text { below) }\end{array}$ \\
\hline $\begin{array}{l}\text { FQI-1, FQI-2, } \\
\text { FQI-3, FQI-4 }\end{array}$ & $\begin{array}{l}\text { Mass Flow Totalizer, } \\
\text { RED LION } \\
\text { CONTROLS, } \\
\text { \#1MD13107 }\end{array}$ & $\pm 0.1 \%$ fs & $\begin{array}{l} \pm 2 \% \text { fs (total error } \\
\text { with above flow } \\
\text { meter) }\end{array}$ \\
\hline $\mathrm{M}-1$ & $\begin{array}{l}\text { Thermocouple Meter } \\
\text { BARNANT } \\
\text { COMPANY, } \\
\text { \#BA600-1040 }\end{array}$ & $\begin{array}{l} \pm 0.4^{\circ} \mathrm{C} \text { and } \pm 0.1 \% \text { of } \\
\text { reading }\left(>-150^{\circ} \mathrm{C}\right)\end{array}$ & N/A \\
\hline
\end{tabular}

